\title{
Growth, Reproduction and Sex Ratios in Oreochromis Andersonii (Castelnau, 1861) Fed with Varying Levels of $17 \alpha$-Methyl Testosterone
}

Kefi AS ${ }^{1 *}$, Kang'ombe $\mathbf{J}^{1}$, Kassam $\mathbf{D}^{1}$ and Katongo $\mathbf{C}^{2}$

${ }^{1}$ University of Malawi, Bunda College of Agriculture, P.O. Box 219, Lilongwe, Malawi

${ }^{2}$ University of Zambia, Department of Biological Sciences, P. O. Box 32379, Lusaka, Zambia

\begin{abstract}
Three different doses $(40,60$ and $90 \mathrm{mgMT} / \mathrm{kg}$ feed) of $17 \mathrm{a}$-methyl testosterone (MT) were administered to Oreochromis andersonii. Growth, reproduction and sex ratios were evaluated. The fish raised on $60 \mathrm{mgMT} / \mathrm{kg}$ feed had the highest final mean weight and this was significantly different $(P<0.05)$ from other hormone doses. Additionally, the $60 \mathrm{mgMT} / \mathrm{kg}$ fed fish had the lowest fecundity and reproductive effort. Histological examination of the gonads did not show any differences between the control and MT fed fish. The gross margin ratio (GMR) of the control group was the highest $(\mathrm{P}<0.05)$. The proportion of males in MT treated groups deviated significantly from the control group although the percentage of males obtained from the $40 \mathrm{mgMT} / \mathrm{kg}$ feed (93.4\%) and $60 \mathrm{mgMT} / \mathrm{kg}$ feed $(94.4 \%)$ fish was insignificant $(P>0.05)$. Furthermore, the highest dose used produced a significantly lower $(P<0.05)$ male proportion (79.3\%) than the other treatments. The anabolic effect of androgen MT diminished over time.
\end{abstract}

Keywords: 17a-methyl testosterone; Growth; Reproduction; Gross margin ratio; Sex ratio

\section{Introduction}

Hormonal use in aquaculture has been successful on reproduction and in monosex production. This is because certain production traits are not similar in both sexes in fish species; therefore, production can be improved by adopting monosex culture technique by either involving the male or female fish depending on the superiority of the growth performance [1]. Furthermore, reproduction in some fish species is impaired in captivity; therefore, hormones are used to induce the fish in order for them to reproduce in captivity or outside their normal breeding period. While hormones have been used as growth promoters in the livestock industry, results in fish seem to be contradictory. For instance the experiments conducted by Soto [2] on Oreochromis niloticus and Hossain et al. [1] on Clarias gariepinus did not show any evidence that growth is enhanced when androgens are administered. According to Robles Basto et al. [3] the use of the androgenic hormone in sex reversal has anabolic effect that enhances growth and protein synthesis, resulting into greater muscle mass gains.

Culture of monosex Oreochromis species, preferably males, has been recognized as the most effective way of avoiding early maturation and uncontrolled reproduction. This is because Tilapia fish exhibits sexually related dimorphic growth in which males grow and reach a larger ultimate size faster than the females [4-6].This can be achieved through manual sexing, hormonal administration and hybridization. Of these hormonal administration has been found to be easy and most effective $[7,8]$. The method involves the use of synthetic or natural steroidal hormone administered to sexually undifferentiated fish at a given dosage and duration. These sex hormones modify secondary sex characteristics and gonads [9]. Of these hormones, the synthetic MT has been widely used $[7,10]$ probably due to its simplicity and reliability.

Although there have been studies $[7,11]$ on the effectiveness of the MT on masculinisation of the O. niloticus, there has been no published information on $O$. andersonii (Three Spotted Tilapia). In addition, research has concentrated on laboratory experiments whose results have produced varying sex reversal success. This study observes the effect of different doses of MT (0, 40, 60 and $90 \mathrm{mgMT} / \mathrm{kg}$ feed) on the growth, reproduction and sex reversal of $O$. andersonii an important fish species in the Zambian aquaculture.

\section{Materials and Methods}

\section{Growth and reproduction}

Eight outdoor concrete tanks $(10 \times 5 \times 0.7 \mathrm{~m})$ were drained, cleaned and allowed to dry for three days (Figure 1). Water was then pumped into them up to the depth of $40 \mathrm{~cm}$ leaving $30 \mathrm{~cm}$ freeboard to avoid the spilling of water since the water was receiving the feed containing the hormone. In addition, the outlet pipes were sealed with plastics. After seven days the tanks were stocked with $O$. andersonii at 1fish/ m2 (50 fish per tank) randomly in a Complete Random Design (CRD) replicated twice for every treatment. Mortality was only observed in the first week of the experiment and was replaced (Table 1). No significant differences $(\mathrm{P}>0.05)$ were observed in the fish stocked among the treatments (Table 1).

Isonitrogenous (30\%) and isocaloric $(4.02 \mathrm{kcal} / \mathrm{g})$ diet was prepared using WinFeed 2.8 package after proximate analyses of ingredients (soyabean $=56 \%$ cake, maize bran $=36 \%$, soyaGold oil $=5.9 \%$, vitamin premix $=1 \%$ and calcium phosphate $=1 \%$ ). Three levels of MT (Aquaculture Solutions Limited, South Africa) of $40 \mathrm{mg} / \mathrm{kg}, 60 \mathrm{mg} / \mathrm{kg}$ and $90 \mathrm{mg} / \mathrm{kg}$ were included in the feed as treatments and hormone free feed as a control. The MT amounts were dissolved in 95\% ethanol at the concentration of $15 \mathrm{ml} / \mathrm{kg}$ of feed [12]. The feed and hormone were then mixed in the dish until a homogeneous sample was achieved. The feed was then dried under direct sunlight for three hours to allow for the evaporation of the ethanol before they were taken on the pelleting machine attached with $3.2 \mathrm{~mm}$ die. The pellets were then taken outside on racks for sun drying before storing in a chiller (Sanyo medicool) at $8^{\circ} \mathrm{C}$ till used.

${ }^{*}$ Corresponding author: Kefi AS, University of Malawi, Bunda College of Agriculture, P.O. Box 219, Lilongwe, Malawi, E-mail: askefi@yahoo.com

Received August 09, 2012; Accepted October 23, 2012; Published October 30, 2012

Citation: Kefi AS, Kang'ombe J, Kassam D, Katongo C (2012) Growth, Reproduction and Sex Ratios in Oreochromis Andersonii (Castelnau, 1861) Fed with Varying Levels of 17a-Methyl Testosterone. J Aquacult Res Dev 3:155 doi:10.4172/2155-9546.1000155

Copyright: ( $2012 \mathrm{Kefi}$ AS, et al. This is an open-access article distributed under the terms of the Creative Commons Attribution License, which permits unrestricted use, distribution, and reproduction in any medium, provided the original author and source are credited. 
Citation: Kefi AS, Kang'ombe J, Kassam D, Katongo C (2012) Growth, Reproduction and Sex Ratios in Oreochromis Andersonii (Castelnau, 1861) Fed with Varying Levels of 17a-Methyl Testosterone. J Aquacult Res Dev 3:155 doi:10.4172/2155-9546.1000155

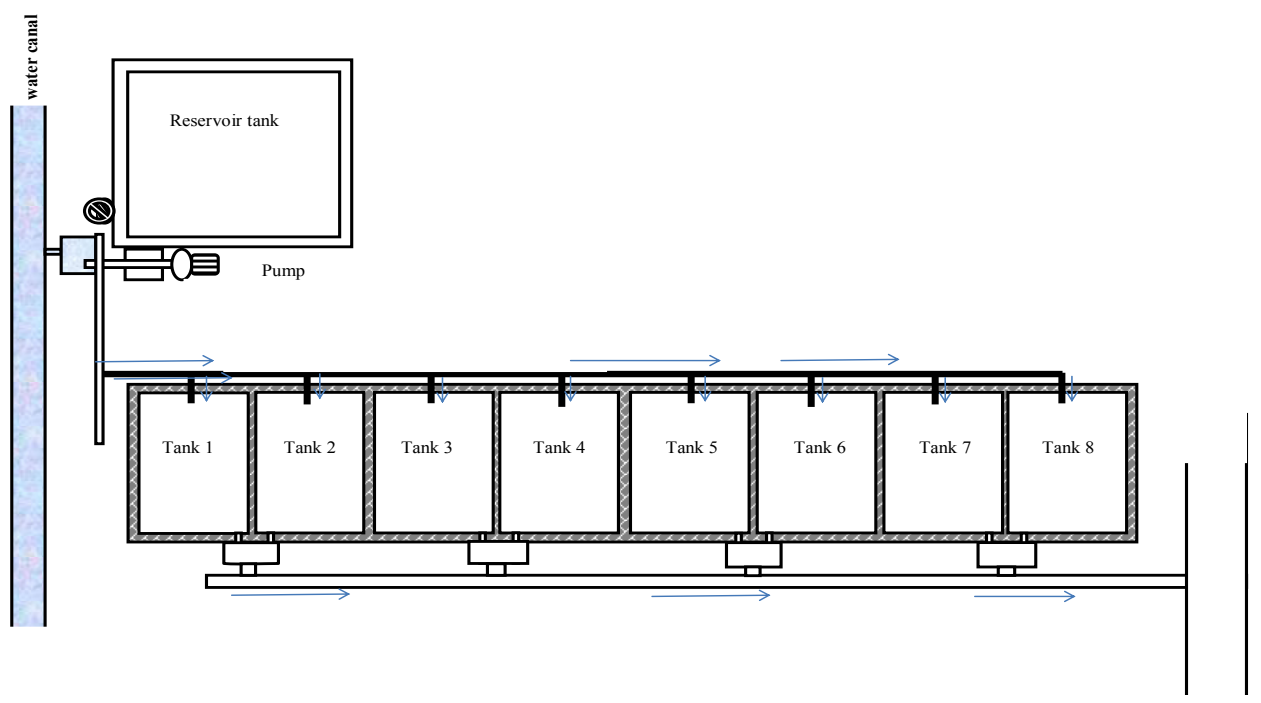

Figure 1: Experimental tanks.

\begin{tabular}{|c|c|c|c|c|}
\hline Treatment & 0 mgMT/kg & 40 mgMT/kg & $60 \mathrm{mgMT} / \mathrm{kg}$ & $90 \mathrm{mgMT} / \mathrm{kg}$ \\
\hline Weight (g) & $8.705 \pm 0.580^{a}$ & $7.995 \pm 0.461^{\mathrm{a}}$ & $8.175 \pm 0.473^{a}$ & $8.983 \pm 0.582^{\mathrm{a}}$ \\
\hline $\mathrm{SL}(\mathrm{mm})$ & $60.650 \pm 1.603^{a}$ & $58.900 \pm 1.284^{\mathrm{a}}$ & $60.200 \pm 1.198^{\mathrm{a}}$ & $61.475 \pm 1.342^{a}$ \\
\hline $\mathrm{TL}(\mathrm{mm})$ & $77.050 \pm 2.130^{\mathrm{a}}$ & $74.150 \pm 1.694^{a}$ & $75.675 \pm 1.616^{\mathrm{a}}$ & $78.950 \pm 1.800^{a}$ \\
\hline No. of fish stocked* & 100 & 100 & 100 & 100 \\
\hline No. of fish died* & 2 & 4 & 3 & 3 \\
\hline
\end{tabular}

Table 1: Weight $(\mathrm{g}), \mathrm{SL}$ and $\mathrm{TL}(\mathrm{mm})$ of the O. andersonii stocked in concrete tanks.

\begin{tabular}{|c|c|c|}
\hline Gonad maturity stage & Gonad appearance of the gonad for males & Gonad appearance of the gonad for females \\
\hline Immature & Testes thin threadlike, flesh coloured, colourless to transparent. & Ovary threadlike, transparent and close to abdomen wall. \\
\hline Inactive & $\begin{array}{l}\text { Translucent testes, wider and generally longer than the ovaries in } \\
\text { inactive female fish }\end{array}$ & $\begin{array}{l}\text { Cream colour, translucent, elongated wider than testis. No oocytes visible } \\
\text { opaque to translucent, occupy half of the visceral cavity. Few oocytes barely } \\
\text { visible. }\end{array}$ \\
\hline Inactive - Active & & $\begin{array}{l}\text { Opaque to translucent, occupy half of the visceral cavity. Few oocytes barely } \\
\text { visible. }\end{array}$ \\
\hline Active & $\begin{array}{l}\text { Dull white/yellowish, thickened and elongated, about } 3 / 4 \text { visceral } \\
\text { cavity. }\end{array}$ & Ovary not yet swollen, but oocytes visible, yellowish with red hue. \\
\hline Ripe & $\begin{array}{l}\text { Cream white, distended fully over length of visceral cavity, milt } \\
\text { evident if testes are cut }\end{array}$ & $\begin{array}{l}\text { Yellow, green or orange eggs characteristic of species, large uniform size. } \\
\text { Occupy all available space in the visceral cavity. }\end{array}$ \\
\hline Ripe running & White/silvery, fully distended, milt runs freely under pressure & $\begin{array}{l}\text { Ovary extremely swollen and eggs run under hand pressure or separate if } \\
\text { ovary is cut. }\end{array}$ \\
\hline Spent & Flesh/red colour shrunken with blood capillaries evident & Flaccid shrunken ovary, reddish with blood and small eggs discernable. \\
\hline
\end{tabular}

Source: Balarin (1983)

Table 2: Morphological description of gonadal maturation of female and male O. andersonii.

The fish were provided with the prepared feed twice a day (10:00 and 15:00 hrs) daily except Sundays calculated at 5\% live body weight of the fish. Fortnightly, a total of 160 fish (20 from each tank or 40 from each treatment) were weighed and lengths (standard length (SL) and total length (TL)) measured according to the procedures described by Skelton [13] after the fish were anaesthetized in $5 \mathrm{~g} / \mathrm{l}$ crude clove (Unilever South Africa Foods (Ptv) Ltd) to reduce stress. The experiment lasted for 119 days.

At the end of the experiment all the fish were caught and their weights and lengths (SL and TL) determined. In addition, 20 fish (10 of each sex) were taken to the laboratory for gonad and liver extraction and weighing for maturity stage [14] (Table 2) and hepatosomatic index (HSI) calculation. The fish were sexed by checking the genital papillae with the help of the magnifying glass (Figure 2). The gonads were then fixed in $10 \%$ formalin in individual vials for later egg counting and diameter determination on an ocular scale mounted to the microscope (Nikon NFX-35) (500x power) after blotting them on paper.

Further 20 gonads (10 of each sex) from every treatment were prepared for the histological examination by fixing them $10 \%$ formalin solution. They were then embedded in paraffin wax after dehydration in series of methanol $(70,80,90,100 \%)$ and sectioned in $3 \mu \mathrm{m}$ and then stained with Haematoxylin and Eosin before they were mounted on slides with DPX mountant. The slides were then examined on the Olympus microscope (150X power) and a picture taken with Kodak camera.

\section{Sex ratio determination}

Oreochromis andersonii breeders were stocked in $250 \mathrm{~m}^{2}$ semiconcrete pond at the sex ratio of 3:1 (female=71.191 $\pm 12.093 \mathrm{~g}$ : 


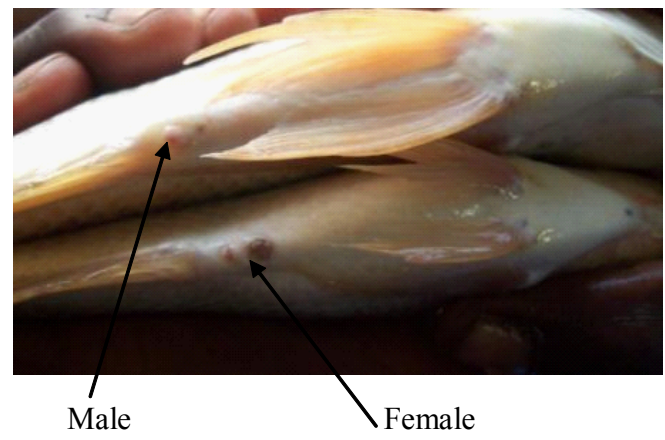

Figure 2: Genital papilla for O. Andersonii.

male $=174.857 \pm 19.828 \mathrm{~g}$; mean $\pm \mathrm{SD})$. After twenty one (21) days, the eggs were recovered from the mouth of the four brooding female fish and were immediately taken to the indoor hatchery for incubation in the jars at $28^{\circ} \mathrm{C}$ with the help of the heater panel immersed in the overhead and bottom tanks. Upon exhaustion of the yolk, the fry were taken to the four concrete tanks $(10 \times 5 \times 0.7 \mathrm{~m})$. Four outdoor concrete tanks were drained, cleaned and allowed to dry for three days. Four hapas $(1 \times 1 \times 1 \mathrm{~m})$ were sown and fixed into four concrete tanks (one hapa in each tank). Water was then pumped into the tanks up to the depth of $40 \mathrm{~cm}$ leaving $30 \mathrm{~cm}$ freeboard to avoid the spilling of water since the water was receiving the feed containing the hormone. In addition, the outlet pipes were sealed with plastics. The hatched spawn were then taken to the set hapas. In order to determine the mean weight of the spawn, 100 fry were put in a beaker (filled with water) with the known weight. The mean weight was calculated as follows:

Mean weight of fry $(\mathrm{g})=\frac{\text { Weight of the beaker with fry }(\mathrm{g}) \text {-weight of beaker }(\mathrm{g})}{100}$

The mean weight of fry was found to be $0.04 \mathrm{~g}$.

A total of 500 fry were stocked in each hapa $\left(500 \mathrm{fry} / \mathrm{m}^{2}\right)$ and treatments allocated randomly to the hapas. The diet as described earlier was fed to fry at $10 \%$ body weight four times a day for 28 days.

At the $29^{\text {th }}$ day, the juvenile fish were scooped from the hapas and transferred into the twelve hapas set in the $750 \mathrm{~m}^{2}$ semi-concrete pond distributed randomly and stocked at $150 \mathrm{fish} / \mathrm{m}^{2}$. The fish were fed a hormone free diet described earlier at 5\% live body weight adjusted monthly after sampling. Mortality was observed and recorded if any daily. During sampling the weights and lengths (SL and TL) of 25 fish from each hapa or 75 fish from every treatment were taken [13].

After three months of rearing, 100 fish from each treatment and control were scooped from the hapas, killed and preserved in $10 \%$ formalin for 10 days before they were dissected for the evaluation of treatment efficacy. Before dissection, the fish were sexed by checking the genital papillae with the help of the magnifying glass by an independent person from the gonadal squash examiner. A gonadal examination technique was carried as described by Guerrero and Shelton [15] on a Nikon profile projector (V-12) (500X power). The presence of previtellogenic or vitellogenic oocytes and the lobular configuration revealed the ovary and testis, respectively and consequently the phenotypic sex [16] or intersex (gonads containing both ovarian and testicular tissues) [17].

\section{Water quality}

Water temperature, $\mathrm{pH}$ and conductivity were determined using
Horiba U-10 water checker while nitrite was determined by an analytically with the samples read on a spectrophotometer.

\section{Data analysis}

Growth, body and reproduction parameters were calculated as follows;

Body weight gain $(\mathrm{g})=$ final weight of fish $(\mathrm{g})$-initial weight of fish $(\mathrm{g})$

Mean daily weight gain $(\mathrm{MDWG})=$ weight gain $(\mathrm{g}) /$ experimental period (day)

Specific growth rate $(\mathrm{SGR})=\left(\left(\ln \mathrm{W}_{\mathrm{f}}-\ln \mathrm{W}_{\mathrm{i}}\right) / \mathrm{t}\right)^{\star} 100$ where $\ln \mathrm{W}_{\mathrm{f}}$ is the natural logarithm of final body weight, $\ln _{\mathrm{i}}$ is the natural logarithm of initial body weight of the fish and $t$ is final time of the experiment in days

Condition factor $(\mathrm{K})=\left(\left(\text { fish weight } /(\mathrm{TL})^{3}\right)^{\star} 10^{5}\right.$, where TL is total length $(\mathrm{mm})$

HSI $(\%)=(\text { weight of liver }(\mathrm{g}) / \text { weight of fish }(\mathrm{g}))^{\star} 100$

Apparent feed conversion efficiency (AFCE) (\%)=fish body weight gain $(\mathrm{g}) /$ total feed provided $(\mathrm{g}))^{\star} 100$

Survival rate $(\%)=(($ Number of fish at the end of the experiment $) /$ Number of fish at the start of the experiment $)^{\star} 100$

Gonadosomatic index $(\%)=($ weight of gonads $(\mathrm{g}) /$ weight of fish $(\mathrm{g}))^{\star} 100$

Fecundity $(\%)=(\text { Number of eggs/weight of fish }(\mathrm{g}))^{\star} 100$

Gonad index $=$ Gonad weight $(\mathrm{g}) / \mathrm{TL}^{3}(\mathrm{~mm})$

Reproductive effort $(\mathrm{RE})=$ fecundity $\times$ egg size $(\mathrm{mm})$

Simple gross margin analysis was performed to determine the cost effectiveness of the prepared diet incorporated with MT. It was assumed that all other operating costs remained constant and only the variable cost of MT was used in calculations using the price (ZK58, 964.18/g) at which it was purchased. The final weights were assumed to be the harvest weight of fish at the prevailing market price of ZK12, 000.00. Key economic indicators were computed according to Faturoti and Lawal [18], and Jolly and Clonts [19].

$$
\mathrm{Y}=\mathrm{P}_{\mathrm{MT}} \mathrm{Q}_{\mathrm{MT}}
$$

Where $\mathrm{Y}=$ Total Cost (TC) of prepared diet incorporated with MT level $(0,40,60$ and $90 \mathrm{mg} / \mathrm{kg}) ; \mathrm{P}_{\mathrm{MT}}=$ Unit cost of MT; $\mathrm{Q}_{\mathrm{MT}}=$ Quantity of MT used at given level $(0,40,60,90 \mathrm{mg} / \mathrm{kg})$.

$$
\mathrm{TR}=\mathrm{P}^{\star} \mathrm{FW}
$$

Where; $\mathrm{TR}=$ Total revenue; $\mathrm{P}=$ price of fish; $\mathrm{FW}=$ final fish weights

$\mathrm{GM}=\mathrm{TR}-\mathrm{Y}$

Where; GM is gross margin, $\mathrm{Y}$ and TR as described in equations above

$$
\mathrm{GMR}=\frac{\mathrm{GM}}{\mathrm{TR}}
$$

Where; GMR is gross margin ratio, $\mathrm{Y}$ and TR as described above

Prior to analysis, parametric data were tested for normality using Shapiro-Wilk test and the homogeneity of variance using Levene's test for equality of variances. General Linear Model (GLM), univariate analysis procedure, was performed to determine the differences among 
Citation: Kefi AS, Kang'ombe J, Kassam D, Katongo C (2012) Growth, Reproduction and Sex Ratios in Oreochromis Andersonii (Castelnau, 1861) Fed with Varying Levels of 17a-Methyl Testosterone. J Aquacult Res Dev 3:155 doi:10.4172/2155-9546.1000155

treatment means deemed at $P<0.05$ followed by Duncan's Multiple Range Test (DMRT) [20]. Cross tabulations and Chi-square tests were used to examine significant differences $(P<0.05)$ in sex ratios among the treatments (MT levels) and between external sexing using genital papillae and gonadal technique. Statistical Package for Social Scientist (SPSS) 15.0 (SPSS Inc) and Stata 12.0 (StataCorp) softwares were used in analyzing the data. Microsoft excel was used in the production of figures and graphs.

\section{Results}

\section{Growth and body index performance}

Significant differences $(\mathrm{P}>0.05)$ were observed in the final mean weight with the control, $40 \mathrm{mgMT} / \mathrm{kg}$ and $90 \mathrm{mgMT} / \mathrm{kg}$ fed fish having similar $(\mathrm{P}>0.05)$ final weights. The $60 \mathrm{mgMT} / \mathrm{kg}$ fed fish had the highest final mean weight and this was significantly different $(\mathrm{P}<0.05)$ from the other treatments and the control (Table 3).

\section{Reproductive performance}

Chi square test showed insignificant differences $(\mathrm{P}>0.05)$ in the

\begin{tabular}{|l|l|l|l|l|}
\hline Treatment & $\mathbf{0} \mathbf{~ m g M T / k g}$ & $\mathbf{4 0} \mathbf{~ m g M T / k g}$ & $\mathbf{6 0} \mathbf{~ m g M T / k g}$ & $\mathbf{9 0} \mathbf{~ m g M T / k g}$ \\
\hline Final weight (g) & $38.211 \pm 1.444^{\mathrm{a}}$ & $38.598 \pm 1.180^{\mathrm{a}}$ & $44.601 \pm 1.414^{\mathrm{b}}$ & $39.918 \pm 1.364^{\mathrm{a}}$ \\
\hline SGR $\left(\%\right.$ day $\left.^{-1}\right)$ & $1.423 \pm 0.464^{\mathrm{a}}$ & $1.543 \pm 0.462^{\mathrm{a}}$ & $1.550 \pm 0.356^{\mathrm{a}}$ & $1.415 \pm 0.362^{\mathrm{a}}$ \\
\hline Weight gain (g) & $29.506 \pm 1.424^{\mathrm{a}}$ & $30.604 \pm 1.058^{\mathrm{a}}$ & $36.428 \pm 1.134^{\mathrm{a}}$ & $30.933 \pm 1.436^{\mathrm{a}}$ \\
\hline MDWG (g) & $0.704 \pm 0.034^{\mathrm{a}}$ & $0.754 \pm 0.034^{\mathrm{a}}$ & $0.808 \pm 0.034^{\mathrm{a}}$ & $0.668 \pm 0.026^{\mathrm{a}}$ \\
\hline K (\%) & $2.139 \pm 0.072^{\mathrm{a}}$ & $2.061 \pm 0.053^{\mathrm{a}}$ & $2.067 \pm 0.063^{\mathrm{a}}$ & $2.089 \pm 0.074^{\mathrm{a}}$ \\
\hline HSI (\%) & $0.115 \pm 0.026^{\mathrm{a}}$ & $0.096 \pm 0.219^{\mathrm{a}}$ & $0.087 \pm 0.017^{\mathrm{a}}$ & $0.128 \pm 0.020^{\mathrm{a}}$ \\
\hline
\end{tabular}

Different superscripts in a row indicate significant difference $(\mathrm{P}<0.05)$

Table 3: Growth performance of $O$. andersonii fed with different levels of feed incorporated with MT (Mean \pm SE)

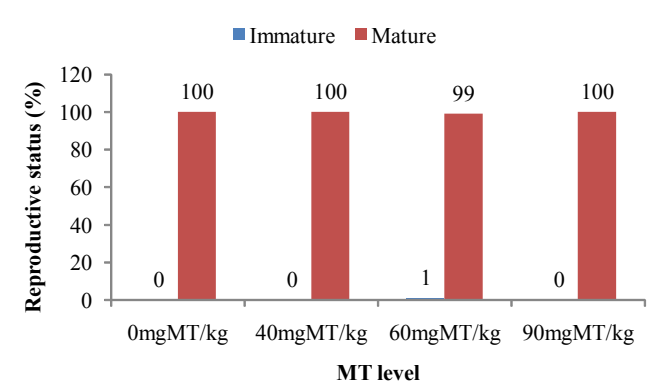

Figure 3: Percentage of immature and mature O. andersonii according to MT level.
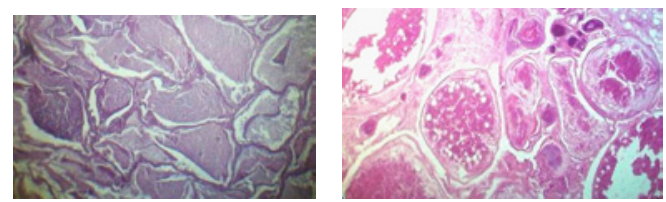

Figure 4a: Testis (left) and ovary (untreated $\mathrm{O}$. andersonii).

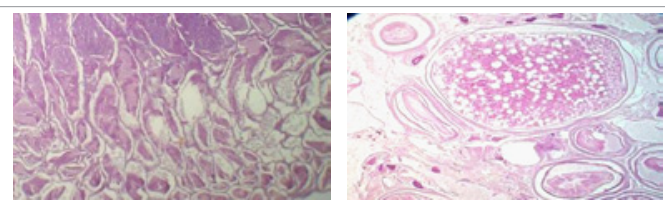

Figure 4 b: Testis (left) and ovary $(40 \mathrm{mgMT} / \mathrm{kg}$ treated $\mathrm{O}$. andersonii).
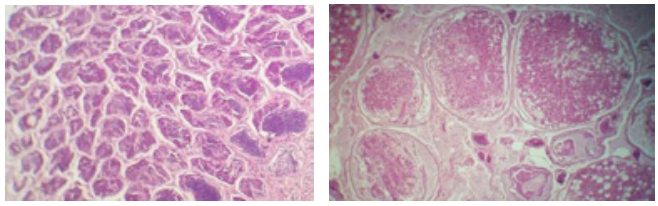

Figure 4c: Testis (left) and ovary (60 mgMT/kg treated O. andersonii)
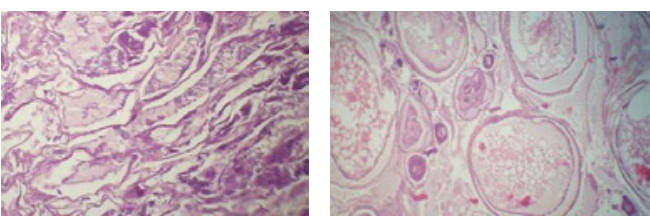

Figure 4d: Testis (left) and ovary (90 mgMT/kg treated O. andersonii).

\begin{tabular}{|l|l|l|l|l|}
\hline Treatment & $\mathbf{0} \mathbf{~ m g M T} / \mathbf{k g}$ & $\mathbf{4 0} \mathbf{~ m g M T} / \mathbf{k g}$ & $\mathbf{6 0} \mathbf{~ m g M T / k g}$ & $\mathbf{9 0 ~} \mathbf{~ g M T} / \mathbf{k g}$ \\
\hline GSI (\%) & $0.738 \pm 0.196^{\mathrm{a}}$ & $0.805 \pm 0.174^{\mathrm{a}}$ & $0.512 \pm 0.160^{\mathrm{a}}$ & $0.751 \pm 0.231^{\mathrm{a}}$ \\
\hline GI (\%) & $33.572 \pm 1.166^{\mathrm{a}}$ & $34.732 \pm 1.167^{\mathrm{a}}$ & $36.181 \pm 0.883^{\mathrm{a}}$ & $34.807 \pm 1.067^{\mathrm{a}}$ \\
\hline $\begin{array}{l}\text { Fecundity } \\
(\%)\end{array}$ & $790.112 \pm 40.177^{\mathrm{b}}$ & $724.368 \pm 32.309^{\mathrm{b}}$ & $500.275 \pm 52.318^{\mathrm{a}}$ & $852.304 \pm 65.817^{\mathrm{b}}$ \\
\hline $\begin{array}{l}\text { Egg size } \\
(\mathrm{mm})\end{array}$ & $0.922 \pm 0.070^{\mathrm{a}}$ & $0.993 \pm 0.049^{\mathrm{a}}$ & $0.888 \pm 0.119^{\mathrm{a}}$ & $0.871 \pm 0.050^{\mathrm{a}}$ \\
\hline $\begin{array}{l}\text { Reproduc- } \\
\text { tive effort }\end{array}$ & $796.136 \pm 79.453^{\mathrm{b}}$ & $755.146 \pm 54.311^{\mathrm{b}}$ & $484.225 \pm 84.071^{\mathrm{a}}$ & $827.835 \pm 98.739^{\mathrm{b}}$ \\
\hline
\end{tabular}

Table 4: Reproductive performance of $O$. andersonii fed with different levels MT (mean \pm SE).

reproductive status of $O$. andersonii subjected to three different levels of MT (Figure 3)

There was a significant $(\mathrm{P}<0.05)$ strong positive correlation between fecundity and number of eggs $(\mathrm{r}=0.936, \mathrm{n}=220, \mathrm{P}<0.05)$ and weight of the ovary $(\mathrm{r}=0.706, \mathrm{n}=220, \mathrm{P}<0.05)$ with high fecundity associated with a large number of eggs and ovary weight. Similarly, a significant $(\mathrm{P}<0.05)$ strong positive correlation was observed between number of eggs and weight of the ovary $(\mathrm{r}=0.814, \mathrm{n}=220, \mathrm{P}<0.05)$ with high number of eggs associated with heavy ovaries. There was no correlation between number of eggs and weight of fish $(\mathrm{r}=0.05, \mathrm{n}=220, \mathrm{P}>0.05)$. There was a significant $(\mathrm{P}<0.05)$ but weak negative relationship between fecundity and weight of fish $(r=-0.270, n=220, P<0.05)$. The size of eggs was positively correlated to ovary weight $(r=0.417, n=220, P<0.01)$ and fecundity $(\mathrm{r}=0.32, \mathrm{n}=220, \mathrm{P}<0.01)$.

Of the reproductive parameters studied, only fecundity and reproductive effort were significant $(\mathrm{P}<0.05)$. The fish fed with 60 $\mathrm{mgMT} / \mathrm{kg}$ feed had significantly lower fecundity and reproductive effort than the rest of the fish in other treatments (Table 4).

The histological examination of the gonads of both sexes were normal with the ovary having different oocyte stages in all the treatments with MT not having any inhibitory effect on the development of the oocytes. The clear oocytes included the perinucleolar, cortical alveolar, vitellogeneic and mature oocytes.

\section{Cost analysis}

The GM declined $(r=-0.25, \mathrm{n}=56, \mathrm{P}>0.05)$ with the level of MT incorporation in the feed although no significant differences $(P>0.05)$ were observed across the treatments. The control had the highest GM followed by the $40 \mathrm{mgMT} / \mathrm{kg}, 60 \mathrm{mgMT} / \mathrm{kg}$ and $90 \mathrm{mgMT} / \mathrm{kg}$ in that order. The GMR was significant $(\mathrm{P}<0.05)$ across the treatments with the 
Citation: Kefi AS, Kang'ombe J, Kassam D, Katongo C (2012) Growth, Reproduction and Sex Ratios in Oreochromis Andersonii (Castelnau, 1861) Fed with Varying Levels of 17a-Methyl Testosterone. J Aquacult Res Dev 3:155 doi:10.4172/2155-9546.1000155

Page 5 of 7

\begin{tabular}{|c|c|c|c|c|}
\hline Parameter & $0 \mathrm{mgMT} / \mathrm{kg}$ & $40 \mathrm{mgMT} / \mathrm{kg}$ & $60 \mathrm{mgMT} / \mathrm{kg}$ & $90 \mathrm{mgMT} / \mathrm{kg}$ \\
\hline TC (ZK) & 0 & $1,926.01 \pm 260.11^{a}$ & $2,973.17 \pm 432.11^{\mathrm{a}}$ & $4,268.37 \pm 589.92^{b}$ \\
\hline TR (ZK) & $16,417.36 \pm 1,732.76^{a}$ & $16,617.78 \pm 1,766.67^{a}$ & $17,537.02 \pm 2,045.53^{a}$ & $16,445.11 \pm 1,867.72^{a}$ \\
\hline GM (ZK) & $16,417.36 \pm 1,732.76^{a}$ & $14,691.77 \pm 1,517.31^{a}$ & $14,563.85 \pm 1,642.05^{a}$ & $12,176.74 \pm 1,322.39^{a}$ \\
\hline GMR & $1.0 \pm 0.000^{d}$ & $0.886 \pm 0.005^{c}$ & $0.837 \pm 0.006^{b}$ & $0.747 \pm 0.010^{a}$ \\
\hline
\end{tabular}

Different superscripts in a row indicate significant difference $(\mathrm{P}<0.05)$.

Table 5: Cost analysis of the of the MT inclusion in the feed fed to O. andersonii for 119 days (mean \pm SE).

\begin{tabular}{|l|l|l|l|}
\hline Treatment & $\mathbf{0} \mathbf{~ m g M T / k g}$ & $\mathbf{4 0} \mathbf{~ m g M T / k g}$ & $\mathbf{6 0 ~} \mathbf{~ m g M T / k g}$ \\
\hline Water temperature $\left({ }^{\circ} \mathrm{C}\right)$ & $23.656 \pm 0.205^{\mathrm{a}}$ & $23.638 \pm 0.212^{\mathrm{a}}$ & $23.645 \pm 0.208^{\mathrm{a}}$ \\
\hline $\mathrm{pH}$ & $6.95 \pm 0.08^{\mathrm{a}}$ & $703 \pm 0.06^{\mathrm{a}}$ & $7.08 \pm 0.07^{\mathrm{a}}$ \\
\hline Conductivity $(\mu \mathrm{S} / \mathrm{cm})$ & $0.096 \pm 0.006^{\mathrm{a}}$ & $0.089 \pm 0.007^{\mathrm{a}}$ & $0.096 \pm 0.006^{\mathrm{a}}$ \\
\hline Nitrite $(\mathrm{mg} / \mathrm{L})$ & $0.114 \pm 0.032^{\mathrm{a}}$ & $0.118 \pm 0.034^{\mathrm{a}}$ & $0.198 \pm 0.114^{\mathrm{a}}$ \\
\hline
\end{tabular}

Different superscripts in a row indicate significant difference $(P<0.05)$

Table 6: Water quality parameters in the MT experiment subjected to O. andersonii for 119 days (mean \pm SE).

\begin{tabular}{|l|l|l|l|}
\hline Treatment & $\mathbf{0 ~} \mathbf{~ g M T / k g}$ & $\mathbf{4 0} \mathbf{~ m g M T / k g}$ & $\mathbf{6 0} \mathbf{~ m g M T / k g}$ \\
\hline Mean weight $(\mathrm{g})$ & $0.254 \pm 0.014^{\mathrm{a}}$ & $0.470 \pm 0.019^{\mathrm{c}}$ & $0.384 \pm 0.032^{\mathrm{b}}$ \\
\hline SL $(\mathrm{mm})$ & $15.960 \pm 0.244^{\mathrm{a}}$ & $20.260 \pm 0.217^{\mathrm{c}}$ & $19.180 \pm 0.374^{\mathrm{b}}$ \\
\hline TL $(\mathrm{mm})$ & $20.680 \pm 0.324^{\mathrm{a}}$ & $26.280 \pm 0.290^{\mathrm{c}}$ & $0.392 \pm 0.024^{\mathrm{b}}$ \\
\hline
\end{tabular}

Different superscripts in a row indicate significant difference $(P<0.05)$

Table 7: Weight and length of fish stocked in the hapas (mean \pm SE).

\begin{tabular}{|c|c|c|c|c|}
\hline Parameter & 0 mgMT/kg & $40 \mathrm{mgMT} / \mathrm{kg}$ & $60 \mathrm{mgMT} / \mathrm{kg}$ & $90 \mathrm{mgMT} / \mathrm{kg}$ \\
\hline \multicolumn{5}{|l|}{ After 30 days } \\
\hline${ }^{*} \mathrm{FMW}(\mathrm{g})$ & $2.656 \pm 0.099^{a}$ & $3.121 \pm 0.092^{b}$ & $2.863 \pm 0.082^{b}$ & $2.601 \pm 0.075^{\mathrm{a}}$ \\
\hline BWG (g) & $2.695 \pm 0.084^{c}$ & $2.053 \pm 0.094^{a}$ & $2.634 \pm 0.010^{c}$ & $2.635 \pm 0.07^{\mathrm{b}}$ \\
\hline SGR $\left(\%\right.$ day $\left.^{-1}\right)$ & $7.834 \pm 0.155^{c}$ & $5.737 \pm 0.153^{a}$ & $7.045 \pm 0.172^{\mathrm{b}}$ & $6.605 \pm 0.153^{b}$ \\
\hline AFCE (\%) & $1727.145 \pm 102.409^{c}$ & $839.784 \pm 47.441^{\mathrm{a}}$ & $1349.180 \pm 76.841^{b}$ & $1143.050 \pm 64.471^{\mathrm{b}}$ \\
\hline \multicolumn{5}{|l|}{ After 60 days } \\
\hline *FMW (g) & $5.311 \pm 0.184^{a}$ & $5.211 \pm 0.144^{a}$ & $4.993 \pm 0.138^{a}$ & $4.840 \pm 0.169^{a}$ \\
\hline BWG (g) & $4.588 \pm 0.233^{a}$ & $4.844 \pm 0.145^{\mathrm{a}}$ & $4.585 \pm 0.138^{a}$ & $4.477 \pm 0.170^{\mathrm{a}}$ \\
\hline SGR $\left(\%\right.$ day $\left.^{-1}\right)$ & $8.292 \pm 0.216^{b}$ & $8.201 \pm 0.153^{b}$ & $7.628 \pm 0.124^{a}$ & $7.852 \pm 0.139^{\mathrm{ab}}$ \\
\hline AFCE $(\%)$ & $118.122 \pm 6.112^{a}$ & $106.138 \pm 3.687^{a}$ & $107.789 \pm 3.628^{a}$ & $116.875 \pm 5.380^{a}$ \\
\hline \multicolumn{5}{|l|}{ After 90 days } \\
\hline${ }^{*} \mathrm{FMW}(\mathrm{g})$ & $6.062 \pm 0.262^{\mathrm{a}}$ & $6.868 \pm 0.204^{a}$ & $6.713 \pm 0.225^{\mathrm{a}}$ & $6.244 \pm 0.279^{a}$ \\
\hline BWG (g) & $5.759 \pm 0.264^{a}$ & $6.444 \pm 0.205^{a}$ & $6.331 \pm 0.224^{a}$ & $5.856 \pm 0.276^{a}$ \\
\hline SGR (\%day $\left.{ }^{-1}\right)$ & $3.310 \pm 0.071^{b}$ & $3.075 \pm 0.041^{a}$ & $3.198 \pm 0.054 a^{b}$ & $3.045 \pm 0.054^{a}$ \\
\hline AFCE (\%) & $63.721 \pm 3.217^{\mathrm{a}}$ & $60.724 \pm 1.940^{a}$ & $62.788 \pm 2.379^{a}$ & $67.221 \pm 3.406^{a}$ \\
\hline
\end{tabular}

Different superscripts in a row indicate significant difference $(P<0.05)$

${ }^{*}$ Final mean weight

Table 8: Growth and feed utilization parameters of $O$. andersonii subjected to different levels of MT.

control group recording the highest ratio, followed by the $40 \mathrm{mgMT} / \mathrm{kg}$ fed fish (Tables 5 and 6).

\section{Growth of sex reversed $O$. andersonii}

By the $28^{\text {th }}$ day, significant differences $(\mathrm{P}<0.05)$ were observed in the weight and length of the fish with the $40 \mathrm{mgMT} / \mathrm{kg}$ feed recording the highest mean weight and length (SL (mm) and TL (mm)) (Table 7).

Significant differences $(\mathrm{P}<0.05)$ were observed in the final mean weight, BWG (g), SGR (\%day $\left.{ }^{-1}\right)$ and AFCE (\%) after 30 days of weaning the fish from MT incorporated feed. The fish subjected to $40 \mathrm{mgMT} /$ $\mathrm{kg}$ feed had the highest final mean weight although the highest weight gain was observed in the control group. Similarly, the SGR $\left(\%\right.$ day $\left.^{-1}\right)$ was significantly highest $(\mathrm{P}<0.05)$ in the control group followed by the 60 $\mathrm{mgMT} / \mathrm{kg}$ fed group. With the exception of SGR $\left(\% \mathrm{day}^{-1}\right)$, the rest of the calculated parameters were not significant $(\mathrm{P}>0.05)$ after 60 days (Table 8).

\section{Sex reversal evaluation}

None of the treatment produced $100 \%$ males. The result of the study revealed no significant differences $\left(\chi^{2}=2.561 ; \mathrm{df}=1 ; \mathrm{P}>0.05\right)$ between hand sex (males $=52.2 \%$ and females $=47.8 \%$ ) and microscopic gonadal examination (males $=47.1 \%$ and females $=52.9 \%$ ) removing intersex gonads, lost gonads and those that could not be identified visually (Figure 5).

Chi square test showed that the number of males from the group treated with $40 \mathrm{mgMT} / \mathrm{kg}$ feed did not differ significantly $(\mathrm{P}>0.05)$ from the $60 \mathrm{mgMT} / \mathrm{kg}$ treated fish.However, the number of $O$. andersonii males treated with $90 \mathrm{mgMT} / \mathrm{kg}$ was significantly lower $(\mathrm{P}<0.05)$ than the 40 and $60 \mathrm{mgMT} / \mathrm{kg}$ groups but significantly higher $(\mathrm{P}<0.05)$ than the control group (Table 9).

\section{Discussion}

Anabolic steroids, both androgens and estrogens, enhance growth $[1,21]$. In this study, the final mean weight of fish fed with $60 \mathrm{mgMT} /$ $\mathrm{kg}$ feed was higher than the control group. However, the control group was not significant different $(\mathrm{P}>0.05)$ from the $40 \mathrm{mgMT} / \mathrm{kg}$ feed and $90 \mathrm{mgMT} / \mathrm{kg}$ feed. Marjan et al. [17] found that $75 \mathrm{mgMT} / \mathrm{kg}$ gave the 


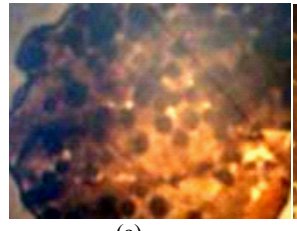

(a)

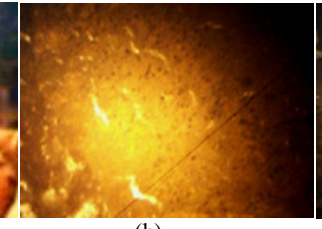

(b)

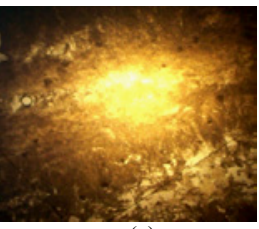

(c)
Figure 5: Female (a), male (b) and intersex (c) gonads in gonadal squash.

\begin{tabular}{|l|l|l|l|}
\hline Treatment & Male (\%) & Female (\%) & Intersex (\%) \\
\hline Control & $54.3^{\mathrm{a} 2}$ & $44.7^{\mathrm{c} 2}$ & $1.0^{\mathrm{a} 1}$ \\
\hline $40 \mathrm{mgMT} / \mathrm{kg}$ & $93.4^{\mathrm{c} 2}$ & $2.2^{\mathrm{a} 1}$ & $4.4^{\mathrm{ab} 1}$ \\
\hline $60 \mathrm{mgMT} / \mathrm{kg}$ & $94.4^{\mathrm{c} 2}$ & $3.3^{\mathrm{a} 1}$ & $2.2^{\mathrm{a} 1}$ \\
\hline $90 \mathrm{mgMT} / \mathrm{kg}$ & $79.3^{\mathrm{b} 3}$ & $14.6^{\mathrm{b} 2}$ & $6.1^{\mathrm{b} 1}$ \\
\hline
\end{tabular}

Different letters (superscripts) in a column (superscripts) indicate significant difference $(P<0.05)$ within the dose (treatment)

Different numbers (superscripts) in a row indicate significant difference $(P<0.05)$ in the gender of the fish within the treatment.

Table 9: Percentage of $O$. andersonii males, females and intersex according to the MT dose.

highest body weight gain which was 1.3 times higher than the control when they studied sex reversed O. mossambicus. Mateen [8] found 70 $\mathrm{mgMT} / \mathrm{kg}$ to have the highest positive effect on the growth indices of O. niloticus. The gain in body weight was also higher than in the 50 and $100 \mathrm{mgMT} / \mathrm{kg}$ treatments. In the current study, the highest dosage showed similar results to $40 \mathrm{mgMT} / \mathrm{kg}$ feed and the control group.

In the sex reversal of Tilapia fish species, several dosages of MT have been used and recommended (50 mgMT/kg [22]; $40 \mathrm{mgMT} / \mathrm{kg}$ [23]; $60 \mathrm{mgMT} / \mathrm{kg}$ [24,25]; $75 \mathrm{mgMT} / \mathrm{kg}$ [17]. Higher doses have been reported to be deleterious and catabolic and therefore reduce growth instead of being anabolic in nature. Jae-Yoon et al. [26] reported a depression in fish growth when the dose of MT was increased from 60 $\mathrm{mgMT} / \mathrm{kg}$ to $80 \mathrm{mgMT} / \mathrm{kg}$ of feed. The MT rate at which growth was maximized coincides with the $60 \mathrm{mg} / \mathrm{kg}$ that has been recommended by other authors [24] on O. niloticus in all male production, the species closest to the fish studied. This study also has found $60 \mathrm{mgMT} / \mathrm{kg}$ feed to be the best in the sex reversal of $O$. andersonii. Therefore, the lower growth exhibited by the 0 and $40 \mathrm{mgMT} / \mathrm{kg}$ may be as a result of having little anabolic effect probably due to its low dosage while the $90 \mathrm{mgMT} /$ $\mathrm{kg}$ might have had catabolic effects and therefore low final mean weight of the fish (O. andersonii) under study.

The effect of MT on gonads appears to be complex [27]. In the current experiment, there was no evidence of MT having an effect on the reproductive characteristics of $O$. andersonii since the GSI, GI and egg size were not significantly different $(\mathrm{P}>0.05)$. This was also confirmed by the functional gonads as observed by the histological examination of the gonads. However, fecundity was significant with $60 \mathrm{mgMT} / \mathrm{kg}$ fed fish having the lowest fecundity. This could be explained by the fact that the fish reared on $60 \mathrm{mgMT} / \mathrm{kg}$ had the highest final mean weight since fecundity is calculated by dividing the number of eggs over the fish body weight. This is supported by the correlation analysis that showed a weak positive relationship $(\mathrm{r}=0.137, \mathrm{n}=220, \mathrm{P}<0.05)$ between the fish weight and ovary weight although fecundity was positively correlated ( $r=0.706, n=220, \mathrm{P}<0.05)$ with ovary weight. However, low fecundity shows that fish fed with $60 \mathrm{mgMT} / \mathrm{kg}$ feed used fewer resources in the egg production. This is confirmed by the reproductive effort which was the lowest among the treatments. In all the fish subjected to different MT levels, there was occurrence of varying eggs indicating development of eggs at different times and that signifies multiple spawning by the
O. andersonii. In this experiment the egg size ranged between $0.1-3.40$ $\mathrm{mm}$. The maximum egg size is less than the 2.1-3.7 $\mathrm{mm}$ reported by Peña-Mendoza et al. [28] in O. niloticus. This is also confirmed by the histological examination of the gonads that revealed oocytes of different stages and sizes in all the treatments used in the experiment.

Gross margin ratio is the ratio of gross profit of a business to its revenue. It is a profitability ratio measuring what proportion of revenue is converted into gross profit (i.e. revenue less cost of goods sold). Higher values indicate that more money is earned per unit amount of revenue which is favourable because more profit will be available to cover non-production costs. The highest ratio was on the control fish with the $90 \mathrm{mgMT} / \mathrm{kg}$ fed fish recording the lowest GMR. This shows that the control group gave more money for revenue collected.

The experiment shows that $O$. andersonii sex reversed raised on 40 $\mathrm{mgMT} / \mathrm{kg}$ and $60 \mathrm{mgMT} / \mathrm{kg}$ feed for the first 30 days after weaning had the highest final body weight. The control group and that of fish given $90 \mathrm{mgMT} / \mathrm{kg}$ feed had similar weights $(\mathrm{P}>0.05)$ among the treatments. Subsequent sampling revealed that FMW (g), BWG (g) and AFCE (\%) were not significant $(\mathrm{P}>0.05)$ but SGR $\left(\%\right.$ day $\left.^{-1}\right)$ seemed to favour the control group followed by the $90 \mathrm{mgMT} / \mathrm{kg}$ fed fish. In unweaned fish, the $60 \mathrm{mgMT} / \mathrm{kg}$ feed produced fish with the highest final mean weight. In an experiment conducted by Pechsiri and Yakupitiyage [29] they found that there were no significant differences $(\mathrm{P}>0.05)$ in FMW (g), SGR $\left(\%\right.$ day $\left.^{-1}\right)$, FCR and survival rate of sex reversed diploid and triploid O. niloticus. Similar results were found on Muskellunge, Esox masquinongy [30].

The results on sex reversal experiment showed that hand sexing was insignificant $(\mathrm{P}>0.05)$ from gonadal squash examination method although the number of males were overestimated by the former method. Using 11-KT, Carlisle et al. [31] found the female Lythrypnus dalli to have developed a male-like genital papilla within five days of androgen implantation probably due to the mediation of the genital papilla as a result of gonadal steroids [32]. Therefore, the insignificant difference $(\mathrm{P}>0.05)$ between the hand sexing and gonadal squash methods may be due to the rearrangement of the genital papilla.

The results of the experiment reveal that the proportion of males in MT treated groups deviated significantly from the control group. However, the percentage of males obtained from the 40 (93.4\%) and $60 \mathrm{mgMT} / \mathrm{kg}(94.4 \%)$ fish was insignificant $(\mathrm{P}>0.05)$. The proportion of males is consistent to what was reported by Phelps et al. [33] (97.8\% males), and [7] (96.8\% males) on O. niloticus who set their experiment in hapas for 28 days at $60 \mathrm{mgMT} / \mathrm{kg}$ feed the protocol similar to the current study. Shepperd [34] and Celik et al. [11] found similar results on Red tilapia in steel tank and aquaria on $O$. niloticus respectively. Romerio et al. [25] too found similar results despite feeding $O$. niloticus with MT incorporated feed for 45 days.

Furthermore, the results showed a significantly lower $(\mathrm{P}<0.05)$ male proportion for the highest dose $(90 \mathrm{mgMT} / \mathrm{kg})$ used in the experiment. This is consistent to what was reported by Okoko [35] on O. niloticus who obtained $99.3 \%$ males at $30 \mathrm{mgMT} / \mathrm{kg}$ feed but only $52 \%$ at 1,200 $\mathrm{mgMT} / \mathrm{kg}$ feed. Marjani et al. [17] on O. mossambicus found $98 \%$ males at $75 \mathrm{mgMT} / \mathrm{kg}$ but only $79.4 \%$ males at $100 \mathrm{mgMT} / \mathrm{kg}$. Das et al. [36] had $96 \%$ males at $60 \mathrm{mgMT} / \mathrm{kg}$ dose but $78.33 \%$ at $120 \mathrm{mgMT} / \mathrm{kg}$ feed. In the current experiment highest MT dose produced only $79.3 \%$ males compared to $94.4 \%$ males at $60 \mathrm{mgMT} / \mathrm{kg}$ feed. This could be as a result of aromatisation of excessive androgens into estrogens.

While the final body weight was highest among the treatments with the feed incorporated with the $60 \mathrm{mgMT} / \mathrm{kg}$ the highest GMR was 
Citation: Kefi AS, Kang'ombe J, Kassam D, Katongo C (2012) Growth, Reproduction and Sex Ratios in Oreochromis Andersonii (Castelnau, 1861) Fed with Varying Levels of 17a-Methyl Testosterone. J Aquacult Res Dev 3:155 doi:10.4172/2155-9546.1000155

observed in the control group (without MT). This shows that biologically the $60 \mathrm{mgMT} / \mathrm{kg}$ can be incorporated in the feeding programme to increase the final body weight. However, non incorporation of the MT in the feed is economical since the GMR was the highest, therefore, incorporation of MT in the feed would just increase unnecessary production costs. Furthermore, the results show that the anabolic effect of androgen MT diminishes over time and that the effect of MT on fish during masculinisation may not be the factor for faster growth in the sex reversed fish. The study reveals that the $60 \mathrm{mgMT} / \mathrm{kg}$ feed produces the highest proportion of males although this is not significant different $(\mathrm{P}>0.05)$ from the $40 \mathrm{mgMT} / \mathrm{kg}$ fed fish. Further, the insignificance difference $(\mathrm{P}>0.05)$ between the hand sexing and gonadal examination provides evidence of identifying the sex reversed fish without using laboratory procedures.

\section{Acknowledgement}

We are grateful to Regional Universities Forum for Capacity Building in Agriculture (RUFORUM) and International Development Research Centre (IDRC) for providing financial support towards this study. The Ministry of Agriculture and Livestock (MAL) through the Department of Fisheries (DOF) and National Aquaculture Research and Development Centre (NARDC), Kitwe, Zambia is sincerely thanked for providing the experimental facilities.

\section{References}

1. Hossain Z, Afruj S, Rahman MM (2002) Effects of different levels of estradiol$17 \beta$ on growth, survival and sex-ratio of African Catfish (Clarias gariepinus, Burchell). Pakistan Journal of Biological Science 5: 355-358.

2. Soto $P(1992)$ Effect of mestanolone (17 $\alpha$-methylandrostan-17 $\beta$-ol-3-one) on sex ratio and growth on Nile tilapia (Oreochromis niloticus). MSc thesis, Auburn University, Alabama, USA.

3. Robles Basto CM, Linan Cabello MA, Mena Herrera A (2011) The effect of growth hormone and sexual reversal on growth of the Nile Tilapia (Oreochromis niloticus). Aquaculture America, New Orleans, Louisiana.

4. Guerrero III RD (1975) Use of androgens for the production of all-male Tilapia aurea (Steindachner). Transactions of the American Fisheries Society 104 342-348.

5. Mair GC, Little DC (1991) Population control in farmed tilapias. Naga 14: 8-13.

6. Manosroi J, Petchjul K, Manosroi A (2004) Effect of fluoxymesterone fish feed granule on sex reversal of the hybrid, Thai red Tilapia (Oreochromis mossambicus Linn.). Asian Fisheries Science 17: 323-331.

7. Green BW, Teichert-Coddington DR (2000) Human food safety and environmental assessment of the use of $17 \alpha$-methyltestosterone to produce male tilapia in the United States. J World Aquaculture Society 31: 337-357.

8. Mateen A (2007) Effect of androgen on the sex reversal, growth and meat quality of Tilapia, Oreochromis niloticus. PhD Thesis, Faculty of Sciences, University of Agriculture, Faisalabad, Pakistani.

9. Yamamoto $T$ (1958) Artificial induction of functional sex-reversal in genotypic females of the medaka (Oryzias latipes). J exp zool 137: 227-263.

10. Khalil WKB, Hasheesh WS, Marie M, Abbas HH (2011) Assessment the impact of 17a-methyltestosterone hormone on growth, hormone concentration, molecular and histopathological changes in muscles and testis of Nile Tilapia; Oreochromis niloticus. Life Science Journal 8: 329-343.

11. Celik I, Guner Y, Celik P (2011) Effect of Orally-Administered $17 a-$ Methyltestosterone at Different Doses on the Sex Reversal of the Nile Tilapia (Oreochromis niloticus, Linneaus 1758). J ANIM VET ADV 10: 853-857.

12. Teichert-Coddington D, Manning B, Eya J, Brock D (2000) Concentration of $17 \alpha$-methyltestosterone in hormonetreated feed: effects of analytical technique, fabrication, and storage temperature. Journal of the world aquaculture society 31: 42-50.

13. Skelton P (2001) A Complete Guide to the Freshwater Fishes of Southern Africa, Struik Publishers, Cape town, Republic of South Africa, pp: 91.

14. Balarin JD (1983) A guide to Tilapia breeding: the Baobab Hatchery Technique. Tilapia culture section Baobab Farm Limited, Mombasa, Kenya.

15. Guerrero III RD, Shelton WL (1974) An aceto-carmine squash method for sexing juvenile fishes. The progressive fish-culturist $36: 56$.
16. Baroiller JF, Fostier A, Cauty C, RognonX, Jalabert B (1996) Effects of high rearing temperatures on the sex ratio of progeny from sex reversed males of Oreochromis niloticus. In R. S. V Pullin, J. Lazard, M. Legendre, J. B. Amon Kothias and D. Pauly (eds). The Third International Symposium on Tilapia in Aquaculture. ICLARM Conference proceedings 41, pp. 575.

17. Marjani M, Jamili S, Mostafavi PG, Ramin M, Mashinchian A (2009) Influence of 17-Alpha Methyl testosterone on Masculinization and Growth in Tilapia (Oreochromis mossambicus). Journal of Fisheries and Aquatic Science 4: 71 74.

18. Faturoti EA, Lawal LA (1986) Performance of supplementary feeding and organic manuring on the production of $O$. niloticus. Journal of West African Fisheries 1: 25-32.

19. Jolly CM, Clonts HA (1993) Economics of Aquaculture, Food products Press, London.

20. Duncan DB (1955) Multiple range and multiple F tests. Biometrics 11: 1-42.

21. Matty AJ (1985) Fish endocrinology. Taylor \& Francis, Croom Helm, London

22. Owusu-Frimpong M, Nijjhar B (1981) Induced sex reversal in Tilapia niloticus (Cichlidae) with methyl testosterone. Hydrobiologia 78: 157-108.

23. Abucay JS, Mair GC (1997) Hormonal sex reversal of tilapias: Implications of hormones treatment application in closed water systems. Aquaculture Research 28: 841-845

24. Tave D (1993) Genetics for fish hatchery Managers. Springer, Van Nostrand Reinhold, New York.

25. Mainardes-Pinto CRS, Fencrich-Verani N, Campos BES, Silva AL (2000) Masculinization of Nile tilapia, Oreochromis niloticus, using different diets and different doses of 17 a-methyltestosterone. Revista Brasileira de Zootecnia 29: 654-659.

26. Jae-Yoon J, Smitherman RO, Behrennds LL (1988) Effect of dietary 17 a methyl testosterone on sex reversal and growth of Oreochromis niloticus. In: The $2^{\text {nd }}$ Symposium on Tilapia in Aquaculture. ICLARM Conference Proceedings by Pullin, R.S.V., T. Bhukaswan, K. Tonguthai and J.L. Macleen (Eds.), 15: 623. Department of Fisheries, Bangkok, Thailand and International Center for Living and Aquatic Resources Management Manila, Philippines: 203-207.

27. Ahmad MM, Shalaby AME, Khattab YAE, Addel-Tawwb M (2002) Effects of 17 a-methyl testosterone on growth performance and some physiological changes of Nile Tilapia fingerlings (Oreochromis niloticus L.). Egyptian journal of aquatic biology and fisheries 4: 295-311.

28. Peña-Mendoza B, Gomez-Marquez JL, Salgado-Ugarte IH, Ramirez-Noguera D (2005) Reproductive biology of Oreochromis niloticus (Perciformes: Cichlidae) at Emiliano Zapata dam, Morelos, Mexico. Rev Biol Trop 53: 515522

29. Pechsiri J, Yakupitiyage A (2005) A comparative study of growth and feed utilization efficiency of sex-reversed diploid and triploid Nile tilapia, Oreochromis niloticus L. Aquaculture Research 36: 45-51.

30. Rinchard J, Dabrowski K, Garcia - Abiado MA, Ottobre J (1999) Uptake and depletion of plasma $17 \alpha-M e t h y l$ testosterone during induction of masculinisation in Muskellunge, Esox masquinongy: Effect on plasma steroids and sex reversal. Steroids 64: 518-525.

31. Carslisle SL, Marxer-Miller SK, Canario AVM, Oliveira RF, Carneiro L, et at (2000) Effects of 11-ketotestosterone on genital papilla morphology in the sex changing fish Lythrypnus dalli. J fish biol 57: 445-456.

32. Oliveira RF, Almada VC (1998) Androgenization of dominant males in a cichlid fish : androgens mediate the social modulation of sexually dimorphic traits. Ethology 104: 841-858.

33. Phelps RP, Cole W, Katz T (1992) Effect of fluoxymesterone on sex ratio and growth of Nile Tilapia, Oreochromis niloticus (L.). Aquaculture Research 23 405-410.

34. Shepperd VD (1984) Androgen sex inversion and subsequent growth of red tilapia and Nile tilapia. Auburn University, USA, pp. 64.

35. Okoko M (1996) Effect of $17 \alpha$ - methyl testosterone concentrations on the sex ratio, and gonadal development on the sex ratio, and gonadal development of Nile tilapia Oreochromis niloticus. MSc thesis, Auburn University, USA.

36. Das NG, AI Mamum F, Barua P, Siddique AA, Chowdhury MSN (2010) Survivality of mono-sex Tilapia (Oreochromis niloticus) fry using 17-a methyltestosterone in a commercial hatchery of Chittagong. Bangladesh. Journal of Aquaculture feed science and nutrition 2: 16-24. 